\title{
Communication of Silence at Martin Heidegger: Sygetics - Logics of Thinking Silence
}

\author{
Ștefan Vlăduțescu \\ Department of Romance Language and Communication, Faculty of Litters, University of Craiova, \\ A. I. Cuza, no. 13, Craiova, Romania \\ E-mail address: stefan.vladutescu@yahoo.com
}

\begin{abstract}
The study explores how Martin Heidegger conceives communication silence. The method used is meta analytic and allows revealing the figure of silence in Heidegger's thinking. In the writings of Martin Heidegger, silence appears as a possibility of communication. Dasein that chooses discourse can opt for silence. Silence is neither the destiny of the language nor is it a random limit for it. It is not silence that is decisive, but discourse. The logic of silence will be called by Heidegger "Sygetics" (in Greek "sigan" means "to be silent"). Silence is a place of thinking. According to Martin Heidegger, Sygetics does not translate the idea that discourse must be replaced by silence. Sigetics is logics of thinking silence.
\end{abstract}

Keywords: communication; discourse; sygetics; thinking silence

\section{INTRODUCTION}

Martin Heidegger discovers silence as a deadlock of universal thought. "Philosophy will never be able to directly trigger a change in the current state of the world, says the German philosopher. Only God would save us" (Apud. Boboc, 1998, p. 20). What remains as a last resort is to prepare in thought and in poesis a state for the advent of God. Philosophy must not forget that it too must contribute to the preparing state in order to wait. Within Heidegger's speculation there is no Christian God, but a principled divinity, "a new God" that Hölderlin referred to and that triggered Nietzsche's anxiety for not revealing himself in two thousand years, a zarathustrian God, that is, a dead God. Meditating on such problems changes at the same time with the problems themselves. Consequently it is admissible for "the way of thought to lead to silence" (Boboc, 1998, p. 20), and "logically such a way is possible". Thought goes primarily towards a cogitating silence.

First of all, the state of the world urges thought into silence. The vigor of inaugural Greek thought is wasted on worries that have no link with the being. This wrong way has the form of an implacable destiny. Philosophy as the science of the being, as it was instituted by the Greek inaugural, must permanently be oriented on the topic of the being. 


\section{LOGICS OF THINKING SILENCE}

Heidegger's discourse apparatus functions in coordination: linguistically and cogitatingly. The language is the fundamental dimension of being and, on the other hand, a way to reveal the being. In that perspective, language defines itself as "more able than us to think and to open", because it constitutes the "shelter of the being" (Heidegger, 1988, p. 321). The essence of the language is thought to come from its correspondence with the Being, to be this correspondence, that is, the sanctuary of human essence. "Language is the language of the being, just like the clouds are clouds of the sky" (Heidegger, 1988, p. 367). The language has its roots in the existential disposition of revealing Dasein, its existential and ontological fundament being the discourse. In relation with the other primary existentials, the discourse represents the utterance of understanding and thus stays at the basis of explanation and enunciation. Language and discourse concatenate in verbalizing the understanding of a way to be in the world of the Dasein. The ratio between themselves is as follows: the language is discourse whose elucidation function becomes obvious within the two possibilities belonging to discourse utterance: "listening and silence" (Boboc, 1998, p. 23) (also, Bilmes, 1994).

The speech that the discourse implies owns, as its possibilities, speech and silence (Heidegger, 2003, p. 161). Silence comes after speech. Speech comes before silence: "in order to be able to fall silent, the Dasein must have something to say" (Heidegger, 2003, p. 165).

Silence appears with Heidegger as a possibility of the discourse: "another essential possibility of the discourse, namely, the silence" (Heidegger, 2003, p. 225). The language that chooses discourse can opt for silence. Silence is neither the destiny of the language nor is it a random limit for it. It is not silence that is decisive, but discourse. It is like a polar star in the dual virtuality. Silence and discourse have the same "existential fundament" (Heidegger, 2003, p. 225): understanding. Only those who understand first can hear and listen. Alternatively, "who is silent during a conversation can suggest, that is, help understanding more genuinely than the one who scatters his words" (Heidegger, 2003, p. 225). Verbose is not the progress basis for comprehension. Actually, it is quite the opposite. Speech that floods with no chances of inserting another speech obstructs what should be understood by bringing an apparent clearness, a place where the trivia incomprehensibility takes over. "To be silent does not mean to be mute" - shows Heidegger (Heidegger, 2003, p. 225).

Alternatively, who is mute has the tendency to speak. A mute has not only proven he can be silent, but he also lacks any possibility to prove something like this". No matter how long silence takes, in the end silence sets in irrevocably. Heidegger's meditation puts language and discourse in the game of linguistic silence, marking the turn of attention, as S. L. Bindemann observes, towards ambiguity and word density. "Heidegger, states Bindemann, shows us how this turn is a return back to the ancient Greek way of thinking that finds its roots in the word logos" (Bindemann, 1981, p. 11). We can thus speak about a silence of the language and about a language of silence. Each of them originates in the discourse existential. At the same time, they acquire an ontological trace which is unbearable for a way of thinking that wants to strictly control everything (Tenescu, 2007; Strechie, 2009; Dima \& Vlăduțescu, 2012c).

Pitagoras and Heraclitus had already taught a lesson of silence: the silence exercises had become a study of silence. The instances of silence culture turned into instances of silent existence (Vlăduțescu, 2011a; Vlăduțescu, 2013b). This education of turning from culture to existence was called paideia by the Greeks. Pitagoras and Heraclitus go for a paideia of silence, discretion, and rest. Otto Pöggeler speaks in this respect about a meeting of Heidegger and Heraclitus in the way they see the logos as "primary putting together". Language is, in its primary quality, putting together, without sound. That is to say language is without speech, it 
is only listening, it is silence. The logos is uttered by staying silent. Through discourse man is given the possibility to utter "is". "Language without sound and putting together of silence is the language of the essence", says Pöggeler (Pöggeler, 1998, p. 237). On the other hand, "language speaks by showing" and because by showing, expanding in all the areas of reaching presence, it allows the appearance and disappearance of something that reaches presence. We are highlighting here the showing quality of language and its silent quality (Baker, 1955; Jensen, 1973; Jaworski, 1997).

The lesson of silence in the sense of the incipient Greeks is taught by Heidegger in the modern philosophy. Between silence and listening, the former is reached anyway. Consequently, silence proves to be the fundamental way of discourse. Certainly, listening cannot choose not to be constitutive itself as well. They are both essential by means of the comprehension that precedes them. It is known that Heidegger proves an ontological precomprehension of the world (Vlăduțescu, 2011b; Vlăduțescu, 2013a). Listening comes from comprehension: when we do not hear well, says Heidegger, we conclude that we do not understand. Listening brings the initial opening of the Dasein for the capability to be. The Dasein hears, because it understands. Comprehension is something already said, already heard. Silence comes from comprehension as well. Comprehensive silence implies. Silence defines itself as a comprehension that the word has not reached: "in order to be able to fall silent, shows Heidegger, the Dasein must have something to say, that is to have its own opening. (Apud Boboc, 1998, p. 24). True silence can only settle in a valid discourse. Without validity, the discourse cannot be silent either. A mute cannot prove he is silent. Certainly, muteness has the tendency to speak, without being able to reach that (Țenescu, 2010; Kenny, 2011; Vlăduțescu \& Ciupercă, 2013).

Discourse fuels the silence. The form in which silence perpetuates is represented by temporality. Whereas the temporality of the Dasein simultaneously generates significations, the temporal impregnation of the discourse constitutes an elusion through comprehension. Time is silent. The discourse takes over the silence: this is Heidegger's linguistic silence.

Language is the "master of man" (Heidegger, 1982, p. 169). As a master, the language speaks supreme. The man speaks only when and only if his discourse is situated within the language, listening to the words that the language addresses to it (Dumitru, 2004; Ghenea, 2006). Listening means listening to the language, not listening by means of the ear. The language, as it can be seen, first in the beginning and then, once more, in the end, indicates the way towards the essence of a thing. The way towards essence is not given spontaneously, as if the essence that is silent were granted and prepared for our access (Dima \& Vlăduțesu, 2012a; Dima \& Vlăduțescu, 2012b). To speak within the language equals listening to the words that the language addresses, in order to guide you, to get that utterance that speaks through silence. By means of listening and silence, the language reveals and keeps in the discourse the being as being. One listens and is silent in the language, because the essence of the language "does not finish in the fact that it is a means of communication" (Heidegger, 1982, p. 197).

Through its content of listening and silence, the language proves to be something else and, moreover, a tool that owns the man among others (Cobley \& Schulz, 2013). It exposes itself as situating, as the one who actually gives the possibility of placement in the middle of the being's opening. Only "where there is language there is world, that is, the ever changing sphere of decision and action, of deed and responsibility" (Heidegger, 1982, p. 197).

Language is "essence on the way" (Heidegger, 1982, p. 176), "the supreme event of the human Dasein": through it, listening and silence are instituted linguistically. In Heidegger's work, besides this linguistic silence there is cogitating silence. The logos is not only linguistically silent, it is also silent cogitatingly. 
"The genuine knowledge of the being is silent", says Heidegger (Apud Boboc, 1998, p. 23). Philosophy is the science of the being. The cogitating apparatus of the discourse finds its form in logic. Philosophical knowledge is silent. In Heidegger we will not find exception. He feel the limits of the language regarding the involvement of silence in the discourse. So, when the latter lacks meaning, Heidegger looks for more instruments in a basically different way than Wittgenstein (Wittgenstein, 1961; Wittgenstein, 2009). Heidegger tries to base linguistic silence on a discoursive-cogitating silence. He demonstrates that the thought which traces the steps of the logos cannot follow the normal logic, it is not allowed to resort to a supra-logic, dialectics, it understands itself only starting from traditional logic (Bigelow, 1982). It cannot escape in logic either, it cannot proclaim a-logic, because everything understands itself starting from logic. "Reasoning the truth of the being, says O. Pöggeler (Pöggeler, 1998, p. 227), must understand itself starting from its own stake ". Its own stake however is not a clear one, certain and transparent. A fundamental trait of the truth of the being is the silence which allows a certain concealment to be concealment (Vlăduțescu, 2012; Vlăduțescu, 2013c).

The thought discourse does not speak about something with the purpose of keeping silent regarding something else that cannot be expressed thoroughly, because it would replace one instance of concealment with another. The silence of thought is verbal, while its utterance is silent. Thus, concealment is given back getting out of concealment. With Heidegger, says Pöggeler, "silence means keeping the concealment by means of silence, while the concealment is seen as mystery that envelops all. The logic of the thought which reasons the truth of the being is the logic of silence, that is, sygetics (Pöggeler, 1998, p. 227). It is not merely an isolated logic of silence. Sygetics points to the essence of language. The logic of silence is on the way to the language (Coșoveanu, 2002; Vlăduțescu, 2004; Vlăduțescu, 2009). It reaches there only as silence. Sygetics is the logic of philosophy, concludes Heidegger: "The logic of silence is the cautious regularity of keeping by means of silence. The logic of silence is the logic of philosophy” (Apud Pöggeler, 1998, p. 227) (also, Llewelyn, 2003, p. 68).

Language should abandon itself to a logic of silence, but this does not exist. Consequently, establishing a logic of the language which devours silence and thus investigates the truth of silence becomes imperative. In Greek "sigan" means "to be silent". The logic of silence will be called by Heidegger "sygetics". According to Otto Pöggeler, sygetics does not translate the idea that "speech must be replaced by silence or that silence must simply acquire a pre-eminence in relation with speech" (Pöggeler, 1998, p. 227). Sygetics does not include in the discourse an irrational side of Heidegger's theory which may try to see silence as silence for a purpose; on the contrary, it brings something obvious: it presents the fundamentally critical and meta-critical feature of thought which is invested in silence.

\section{CONCLUSION}

Philosophical knowledge is silent. The cogitating apparatus of the discourse finds its form in logic. Feeling the limits of the language regarding the involvement of silence in the discourse, when the latter lacks meaning, Heidegger looks for more instruments in a basically different way than Wittgenstein. Heidegger tries to base linguistic silence on a cogitating silence. Heidegger's logos speaks the language of silence. Moreover, it judges in the logic of silence. Unlike L. Wittgenstein, Heidegger does not find a limit in silence, but a way to develop the logics of thinking silence: Sygetics. 


\section{References}

[1] Baker S., Journal of General Psychology 53 (1955) 145-167.

[2] Bigelow P., Continental Philosophy Review 15(1) (1982) 67-82.

[3] Bindemann, S.-J. (1981). Heidegger and Wittgenstein: The Poetics of Silence. Washington: University Press of America.

[4] Boboc A. (1998). Semiotică şi filosofie - Texte de referinţă. Bucureşti: Editura Didactică şi Pedagogică.

[5] Borowski A., International Letters of Social and Humanistic Sciences 1 (2013) 19-27.

[6] Cobley P., Schulz P. J. (2013). Introduction. In P. Cobley \& P. J. Schulz (Eds.), Theories and Models of Communication (pp. 1-16). (Vol. 1). Walter de Gruyter.

[7] Coşoveanu M. (2002). Quick Approach to Shakespeare's Plays. Craiova: Editura Universitaria.

[8] Dima Ioan Constantin, Vlăduțescu Ștefan (2012a). Persuasion Elements Used in Logistical Negotiation: Persuasive Logistical Negotiation. Saarbrucken: LAP Lambert.

[9] Dima Ioan Constantin, Vlăduţescu Ştefan (b). European Journal of Business and Social Sciences 6(1) (2012) 27-33.

[10] Dima Ioan Constantin, Vlăduţescu, Ştefan (c). International Journal of Management Sciences and Business Research 1(9) (2012) 1-11.

[11] Dumitru M. (2004). Explorări logico-filosofice. Humanitas.

[12] Ghenea V., Analele Universitatii din Craiova, Seria Filozofie (17) (2006) 157-165.

[13] Heidegger M. (1982). Originea operei de artă. Bucureşti: Editura Univers.

[14] Heidegger M. (1988). Repere pe drumul gândirii. Bucureşti: Editura Politică.

[15] Heidegger M. (2003). Fiinţă şi timp. Bucureşti: Editura Humanitas.

[16] Jaworski A. (Ed.). (1997). Silence: Interdisciplinary Perspectives. New York: De Gruyter.

[17] Jensen J. V., ETC 30 (1973) 249-257.

[18] Kenny C. (2011). The Power of Silence. Silent Communication in Daily Life. London: Karnac Books.

[19] Llewelyn J. (2003). Prolegomena to Any Future Phenomenological Ecology. In C. S. Brown \& T. Toadvine (Eds.), Eco-Phenomenology, back to the Earth Itself (pp. 51-72). New York: SUNY Press.

[20] Pöggeler O. (1998). Drumul gândirii lui Heidegger. Bucureşti: Humanitas.

[22] Strechie M., Analele Universității din Craiova (2009) 92.

[23] Tenescu A., Cuadernos de filología francesa (18) (2007) 209-220.

[24] Țenescu A., Analele Universității din Craiova (2010) 518.

[25] Vlăduţescu Ştefan (2004). Comunicologie şi Mesagologie. Craiova: Editura Sitech. 
[26] Vlăduțescu Ştefan (2009). Concepte şi noţiuni de Comunicare şi Teoria mesajului. Craiova: Editura Sitech.

[27] Vlăduțescu Ştefan (a), Revista de psihologie 57(3) (2011) 201-213.

[28] Vlăduțescu Ştefan (b), Revista de psihologie 57(4) (2011) 359-366.

[29] Vlăduțescu Ştefan, Revista de psihologie a Academiei Române 58(1) (2013) 57-64.

[30] Vlăduțescu Ștefan (a), Jokull Journal 63(8) (2013) 186-197.

[31] Vlăduțescu Ștefan (b), Jokull Journal 63(9) (2013) 301-318.

[32] Vlăduțescu Ștefan (c), Revista de psihologie 59(3) (2013) 254-263.

[33] Vlăduțescu Ștefan, Ciupercă Ella Magdalena (2013). Next Level of Communication: Social Networks. Aachen: Shaker Verlag.

[34] Wittgenstein L. (1961). Tractatus Logico-Philosophicus. London: Routledge \& K. Paul.

[35] Wittgenstein L. (2009). Philosophical Investigations. (4th ed.) Oxford: Wiley. 